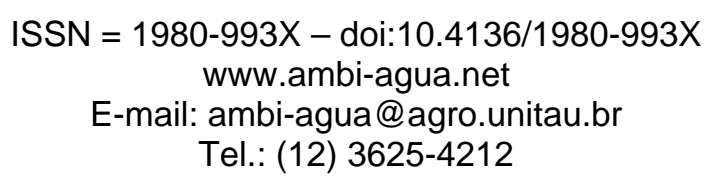

\title{
Pollution in the estuary of the Baracoa river, La Habana, Cuba
} (doi:10.4136/ambi-agua.173)

\author{
Lisset Susana Cobas Gómez ${ }^{1}$; Eusebio Perigó ${ }^{2}$; Roberto Piñeiro ${ }^{1}$; Regla Duthit Somoza ${ }^{3}$ \\ ${ }^{1}$ Centro de Investigaciones Pesqueras \\ 5ta Ave. y 246, Barlovento, Sta. Fe, Playa. Ciudad Habana. Cuba. CP: 19100, Cuba \\ E-mail: susana@cip.telemar.cu; robertop@cip.telemar.cu \\ ${ }^{2}$ Instituto de Oceanología \\ Ave. 1ra No.18406 Reparto Flores, Playa, La Habana, Cuba \\ E-mail: ecomar@oceano.inf.cu \\ ${ }^{3}$ Instituto Nacional de Pesquisas Espaciais - INPE, Centro de Previsão de Tempo e Estudos Climáticos - CPTEC \\ Avenida dos Astronautas, 1758, Jd. Granja, 12227-010 São José dos Campos, SP, Brasil \\ E-mail: regla@dsr.inpe.br
}

\section{ABSTRACT}

The environmental quality of the Baracoa river estuary was studied from the physic (temperature and salinity), chemic variables (dissolved oxygen, oxygen biochemical demand (DBO), oxygen chemical demand (DQO), nitrogen cycle, inorganic phosphorus and total phosphorus) and the microbiological variables (total and thermotolerant coliforms and faecal streptococci). The samplings were made on February 2006, May and October 2007. Spatial distribution of the physical and chemical parameters measured suggests that the estuary is dominated by the marine conditions. The salinity and temperature analyses show that in general the characteristics of the estuary could be influenced by the contribution of the river basin drainage. In general, the concentrations of the measured parameters in the Baracoa river estuary, strongly suggest that this area is under influence of human activities on the river basin, due to the low levels of dissolved oxygen and an oxygen average deficit of $-1.6 \mathrm{mg} / \mathrm{L}$. nthropogenic actions in this estuary are mainly related to the emission of domestic and farming rejects without suitable treatment. This is visibly associated with the observed values of the total coliforms concentrations as well as the concentration of faecal streptococci, that surpassed reference values from the Cuban norm for water quality, following on bad or doubtful quality levels pointing out negatively measurements made next to the communication channel the estuary and the El Doctor lagoon.

Keywords: environmental quality; estuary; river; physic and chemical variables; microbiological variables.

\section{Poluição no estuário do rio Baracoa, La Habana, Cuba}

\section{RESUMO}

Neste trabalho foi analisada a qualidade ambiental do estuário do rio Baracoa por meio das variáveis físico-químicas (oxigênio dissolvido, a demanda bioquímica de oxigênio DBO, demanda química do oxigênio - DQO, ciclo de nitrogênio, fósforo inorgânico e fósforo total) e as variáveis microbiológicas (coliformes totais e coliformes termotolerantes e estreptococos fecais). As amostragens foram feitas em fevereiro de 2006, maio e outubro de 2007. A distribuição espacial dos parâmetros medidos sugere que o estuário é dominado pelas condições marinhas. As análises de temperatura e salinidade mostram que as características do estuário poderiam ser influenciadas pelas contribuições da drenagem da bacia através das chuvas. Em geral, as concentrações dos parâmetros medidos no estuário do rio Baracoa, sugerem que essa área é impactada pelas atividades humanas na bacia do rio, devido aos baixos níveis de oxigênio dissolvido e a média do déficit de oxigênio de $-1.6 \mathrm{mg} / \mathrm{L}$. As 
atividades antropogênicas no estuário estão relacionadas às emissões de desperdício doméstico e agrícola sem tratamento. Isso está, provavelmente, associado aos valores observados das concentrações de coliformes totais assim como as de estreptococos fecais, os quais superaram os valores de referência da norma cubana de qualidade d' água, caracterizada como de qualidade baixa ou duvidosa. Ressaltando-se negativamente as medidas feitas perto do canal de comunicação entre o estuário e a laguna O Doutor.

Palavras-chave: qualidade ambiental; estuário; rio; variáveis físico-químicas; variáveis microbiológicas.

\section{INTRODUCTION}

Estuary is defined as a water body partially closed that receives freshwater from the rivers and are in contact with the sea water which penetrates it by the effect of tides, slowing down the exit of fluvial water which both causes certain mixture of types of water (Lauff, 1962; Contreras, 1993). Many estuaries and rivers have been used like final receivers of the polluting sources. They stand out as contribute of the industrial remainders, the polluting agents from the residual agriculture activities and the domestic ones (Perigó et al., 2002).

Groundwater is increasingly being subjected to over-exploitation for agricultural, urban and industrial uses, leading to the deterioration of groundwater in coastal areas through saltwater intrusion. Additional problems such as the discharge of untreated or inadequately treated wastewater, agricultural runoff from farms and discharge of untreated sewage can all lead to the deterioration and contamination of groundwater in coastal aquifer. One of the main impacts observed in estuaries is the eutrophication process that is caused by the increase of the contribution of nutrients (example: carbon, nitrogen, phosphorus, etc.). This process brings modifications of the environmental conditions to these areas through the excessive growth of seaweed, reduction of the dissolved oxygen and the microbiological contamination (Cloern, 2001). In Cuba many estuaries have been contaminated because of the industrial, the domestic and the farming activities, in addition the hydrology of these ecosystems has been altered significantly because of damming rivers, buildings construction for harbor facilities and mangrove cutting for industrial, agricultural and tourist activities (Baisre, 2004).

The role of groundwater in delivering contaminants to coastal water has become an area of growing interest and concern. Although many types of chemical constituents have contaminated coastal estuarine systems, much of the concern to date has been focused on the discharge of excess pollutants into coastal ecosystems. Nutrient contamination of coastal groundwater occurs as a consequence of activities such as wastewater disposal from septic systems and agricultural and urban uses of fertilsers. The estuarine hydrochemical characterization is fundamental for the understanding of these areas, being able to be used as indicating of the influence of natural or anthropogenic sources. For these reasons the main objective in the present work is to determine the environmental quality of the Baracoa river estuary through monitoring physic, chemical and microbiological variables.

\subsection{Physic and geographical characteristics from the study area}

The Baracoa River is a fluvial current, its waters run from south to north in The Habana province, spilling it directly to the sea, with west direction along the coast forming the beach with the same name. It has a length of $13.8 \mathrm{~km}$ and the total area of its river basin is 10.72 $\mathrm{Km}^{2}$ (CNNG, 2000). The river estuary has shallow waters, with an average depth of $1.9 \mathrm{~m}$. Receives freshwater contributions from the river, land draining in the rainfall season and from the coastal lagoon El Doctor. Measurements made by Perigó et al. (2008) in the rainfall season allowed us to know that the current in the estuary had a preferential direction SSE (South southeast) and an speed inferior to $8 \mathrm{~cm} / \mathrm{s}$.

The Baracoa river estuary is located in the coastal zone of the Bauta municipality. Its geographic situation is between $23^{\circ} 02^{\prime} 35^{\prime \prime}$ and $23^{\circ} 02^{\prime} 55^{\prime \prime}$ North latitude and $82^{\circ} 34^{\prime} 17^{\prime \prime}$ and 
$82^{\circ} 34^{\prime} 29^{\prime \prime}$ west longitude (Figure 1). Its surrounding vegetation is formed fundamentally by red mangrove (Rhizophora mangle), dark mangrove (Aviccennia germinans) and white mangrove (Laguncularia racemosa). This vegetation, like other ecosystems, has undergone a remarkable reduction due to its indiscriminate cutting (González Sansón, 2002).

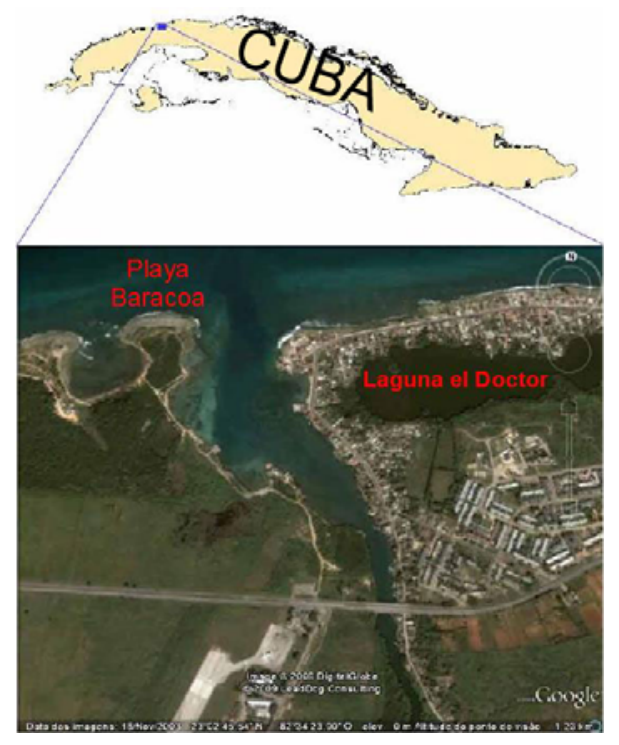

Figure 1. The Baracoa River Estuary, Cuba, adapted from Image 18/11/2003, Google Earth.

The estuary communicates with "El Doctor" lagoon through a contracted channel with highly contaminated water as a result of pouring domestic residual. The lagoon receives this kind of residual from "Los Cocos" community, in addition to other polluting sources like a polyclinic, a restaurant and the surrounding population, which has contributed to the alteration of its hygienic quality (Figure 2). The Baracoa River receives residuals that come from agriculture activities like: pig barley and greater livestock, birds farming, industrial activities and land erosion by other economical activities. Also collect fertilizers composed by organ phosphorus and organ chlorinated which are used in agriculture, as well as heavy herbicides and metals with bio accumulative effects on marine and estuarine freshwater biota (Perigó et al, 2008). The river is dammed, which constitutes another anthropogenic pressure action that trends to increase the salinity (Baisre, 2000). Consequently the hydrostatic balance between the estuary and seawater interface can be broken, causing seawater intrusion into the aquifer and thereby causing deterioration of the water quality.

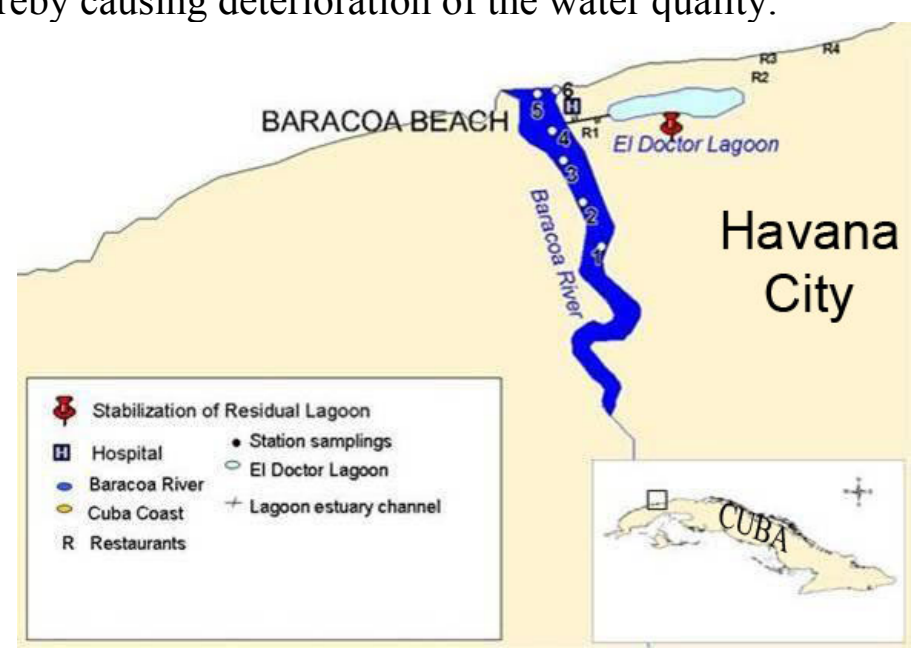

Figure 2. Network stations and main polluted focus in the estuary and the coast of Baracoa River. 


\section{MATERIALS AND METHODS}

The Baracoa River estuary has a 2750 meters long, the station samplings were taken with an approximately 200 meters distance and were studied the estuary section of 1220 meters. The water samples were took in the centre of the estuary, at the surface and bottom levels according to the depth (Figure.2), with a Petersen - Nansen bottle, connected with a reversible thermometer. It was made three investigations cruises, taking place on: February 2006, May and October 2007.

In each station was measured the depth with a breakdown, the positions from the stations with a GPS GARMIN MAGALLANES MOD 3000 XL, the transparency with a Disco Secchi and the water temperature with a reversible thermometer. Using the Winkler method Alberster modification was determined the dissolved oxygen (DO) in situ. The biochemical oxygen demand (DBO5) was made by the method of direct incubation during 5 days to $20^{\circ} \mathrm{C}$ in dependency of the organic matter concentration from APHA et al. (1992). The salinity was measured by a salinometer.

In order to quantify the nitrogen and phosphorus cycles were preserved on freezing until their analysis. Chemical oxygen demand (DQO) was take by oxidation in a basic medium with potassium permanganate (FAO 1975), and ammonia ( $\mathrm{NH}^{+}$) by the indophenol blue method. Nitrite was measured by the photometrical method spectra of the Griess reaction, nitrates by reduction with inorganic cadmium and phosphorus by method of the phosphomolybdenum, reduction with ascorbic acid, all according to IOC- UNESCO (1993). Total nitrogen was determined by digestion with potassium persulphate in alkaline medium and later determination as nitrate and the total phosphorus by digestion of the samples with potassium persulphate and later determination as inorganic phosphorus, methodology of Pierre Carmouze (1994). The concentrations of total thermotolerant coliforms and faecal streptococci were determined following the standard methodology of multiple tubes with five retorts (NMP), proposed by APHA et al. (1992). Also there were evaluated according to the Cuban norm (Cuba, 1999b) with direct contact.

A statistical analysis were made to know the data origin, for example, was done a normality analysis and was obtained that the data distribution is normal for $\alpha 0.05$. The mean salinity values were used for analysis, because it was considerate by Bendis (1999) as an important approach for the distribution and hydrodynamic of estuaries. The Statistic package $\mathrm{R}$ was used in this case to do a simple variance analysis (ANOVA), which is made by comparing means between moths. Finally, a cluster analysis was done using the agglomerative method, selecting the Euclidean distance to compare the differences between study months selecting the Euclidean distance in the Statgraphic Centrurion XV (version 15.2.05) program.

\section{RESULTS AND DISCUSSION}

The physical and chemical measured parameters were summarized with the average of the three investigation cruises on the estuary. Also the Table 1 shows the standard deviation and the minimum and maximum values observed.

The estuary has shallow waters with $1.92 \mathrm{~m}$ depth; that is why was observed a total transparency in the whole water body. The temperature values range was between 24.50 and $30.20^{\circ} \mathrm{C}$. The inferior values were registered on February 2006, logically, because this parameter is based on the weather season and the daily time in which the specific measurement is made (winter season for the North hemisphere). 
Table 1. Physic and chemical parameters in superficial waters level for the estuary.

\begin{tabular}{l|c|c|c|c|c}
\hline \multicolumn{1}{c|}{ Parameter } & Unit & Average & D.S & Minimum & Maximum \\
\hline Temperature & ${ }^{\circ} \mathrm{C}$ & 28.10 & 1.90 & 0.50 & 30.20 \\
Salinity & $\mathrm{ppm}$ & 34.80 & 0.30 & 31.60 & 36.60 \\
Disolved Oxygen (DO) & $\mathrm{mg} / \mathrm{L}$ & 5.10 & 1.30 & 2.90 & 8.90 \\
Deficit of $\mathrm{O}_{2}$ & $\mathrm{mg} / \mathrm{L}$ & 1.50 & 1.10 & 3.20 & 4.00 \\
Oxygen Saturation & $\%$ & 6.20 & 0.20 & 6.00 & 6.60 \\
$\mathrm{DBO}_{5}$ & $\mathrm{mg} / \mathrm{L}$ & 4.50 & 1.80 & 2.10 & 8.70 \\
$\mathrm{DQO}$ & $\mathrm{mg} / \mathrm{L}$ & 5.6 & 2.2 & 3.0 & 9.0 \\
$\mathrm{NO}_{3}+\mathrm{NO}_{2}$ & $\mu \mathrm{mol} / \mathrm{L}$ & 4.24 & 5.55 & 0.19 & 22.85 \\
$\mathrm{NH}_{4}$ & $\mu \mathrm{mol} / \mathrm{L}$ & 3.51 & 2.20 & 0.59 & 7.65 \\
$\mathrm{NO}$ & $\mu \mathrm{mol} / \mathrm{L}$ & 43.84 & 36.09 & 2.44 & 101.42 \\
$\mathrm{NT}$ & $\mu \mathrm{mol} / \mathrm{L}$ & 51.58 & 38.77 & 4.87 & 125.84 \\
$\mathrm{PO}_{4}$ & $\mu \mathrm{mol} / \mathrm{L}$ & 0.52 & 0.76 & 0.04 & 2.91 \\
$\mathrm{Total}$ Phosphorus $(\mathrm{P} \mathrm{T})$ & $\mu \mathrm{mol} / \mathrm{L}$ & 2.50 & 4.13 & 0.45 & 17.51 \\
\hline
\end{tabular}

\subsection{Salinity}

Salinity is an important factor for the physic and chemist conditions on the estuary. Although, in the present work was not made an estuary zone demarcation, Kjerfve (1987) propose that the marine influence in these areas should be analyzed taking into account the salinity spatial variability on the estuary.

The salinity presented a few variability with an average of $34.8 \pm 0.3 \mathrm{ppm}$ next to the reported for marine waters, which are around $36 \mathrm{ppm}$. Thus, the estuary can be considered as homogenous or very mixed (Lauff, 1962). On the sampling made on May 2006 was observed that salinity declined flux up river to station E-1 where first arrives the freshwater influence. This freshwater average fraction was $4.4 \%$ for the whole area, which can be associated to the influence exerted by the river damming.

However, the main variation ranged was observed in October 2007 (Figure 3) with 31.6 ppm on the fourth station and $36.6 \mathrm{ppm}$ on the second. It was assumed by Perigó et al. (2008) that this feature is caused by the polluted waters which arrives from "El Doctor" coastal lagoon. Marins et al. (2003) affirmed that, in some environments, this inversion process of the salinity distribution for estuaries could be related to coastal lagoons and existing dams in the river basins, which reduce the fluvial flux that arrives to the estuary favoring the marine water intrusion.

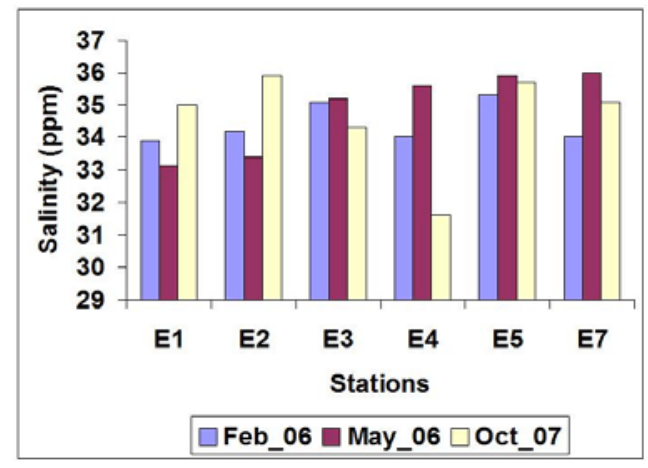

Figure 3. Salinity distribution for the Baracoa River estuary. 


\subsection{Statistical analysis}

The ANOVA test show no significant differences on the correlation values (Table 2).

Table 2. Variance analysis.

\begin{tabular}{lccccc}
\hline Source & Sum Squares & GL & Mean Square & F & Value-P \\
\hline Between groups & 0.065 & 2 & 0.03 & 0.02 & 0.98 \\
Inter groups & 20.78 & 12 & 1.73 & - & - \\
Total (Corr.) & 20.85 & 14 & - & - & -
\end{tabular}

In the cluster analysis was obtained two sets corresponding to 1) February and May and 2) October. Taking into account this analysis was observed differences between the first two month and October for the salinity gradient behavior along those sets (Figure 4).

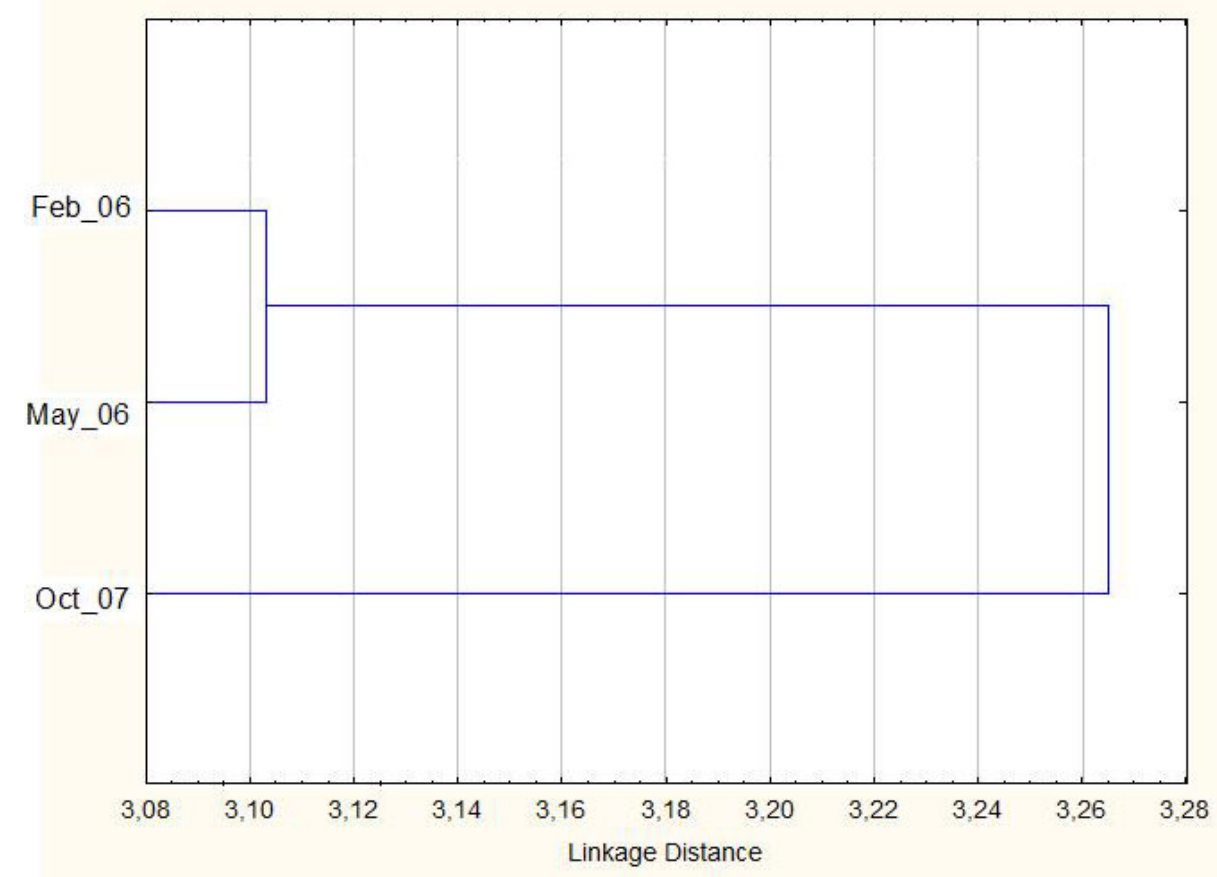

Figure 4. Cluster analysis between cruises.

\subsection{Dissolved oxygen}

The dissolved oxygen concentrations often were inferior to the saturation value. When cruises correspond to rainfall season (Figures $5 \mathrm{~b}$ and $5 \mathrm{c}$ ) an oxygen deficit was $-1.6 \mathrm{mg} / \mathrm{L}$, attributed to high biological oxygen consumption on the water column and the sediment predominance.
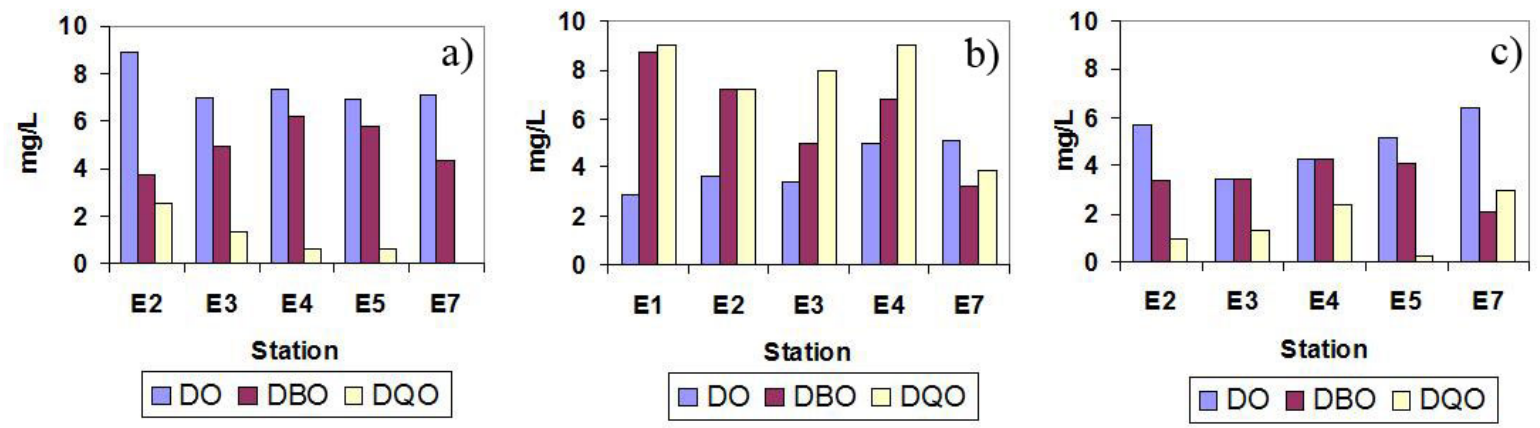

Figure 5. Distribution of DO (mg/L), $\mathrm{DBO}_{5}(\mathrm{mg} / \mathrm{L})$ y DQO (mg/L) on (a) February 2006, b) May 2007 and (c) October 2007. 
On February and October was observed oxygen contents superior to $5 \mathrm{mg} / \mathrm{L}$ (Figures 5a and 5c). On May 2007 values where the smallest amount measured on the estuary (Figure 5b), because the organic matter transport increase in the coastal lagoon channel due to rainfall, which bring to the estuary considerable contributions of organic matter concentrations (Perigó et al., 2006, 2008). Despite the gas amounts on the estuary are higher than those were reported on Agabama, Zaza and Las Casas rivers estuaries, where there are anoxic areas and hypoxia is common (Perigó et al., 1999).

The estuarine portion of the Baracoa River was characterized for having an organic matter which is easily biodegradable. The water body are contaminated by organic matter concentrations based on the $\mathrm{DBO}_{5} 20$ behavior ranged from 2.1 to $8.7 \mathrm{mg} / \mathrm{L}$ (Table 1), taking into account the established norm for this variable (Cuba, 1999b). In May 2007, on the remotest points from the estuary mouth E-1, E-2 was found high concentration of this matter, also at point E-4 (Figure 4b). The sampling points E-3 and E-4 showed the highest concentration of $\mathrm{DBO}_{5} 20$ in October (Figure 4c). The established amounts of $\mathrm{DBO}_{5} 20$ by Cuban norm (Cuba, 1999b) are $2 \mathrm{mg} / \mathrm{L}$ for fishing activities in suitable marine water. The observed values of organic matter concentration are out of rules and also were higher than those ones reported by Perigó et al. (1999) and Montalvo et al. (1999), for the coastal lagoons of the estuarine complexes of Cauto, Agabama and Zaza rivers.

The DQO presented the highest concentrations in May 2007 (Figure 5c). The distribution pattern were similar to $\mathrm{DBO}_{5}$ (Table 1), with values ranged from 3 to $9 \mathrm{mg} / \mathrm{L}$. The minimum corresponds to marine water contaminated by organic matter according to the EQS (Japan, 2002) of Japan, this norm considers that values $\pm 3 \mathrm{mg} / \mathrm{L}$ of DQO in sea water belong to water contaminated by organic matter. Between both variables a significant correlation was 0.93 and the relate equation was:

$$
\mathrm{DQO}=1.11 \times \mathrm{xBO}+0.59
$$

On this equation the organic matter degree of biodegradability is deduced assuming that DBO - DQO relation is approximately $1: 1$, therefore is $100 \%$.

The relationship between oxygen and the $\mathrm{DBO}_{5}$ showed an average value of $1.3 \pm 0.7$, corroborating that microbiologically the gas concentrations are insufficient to disturb the organic matter water existing. Even the quantities of organic matter quantities can trigger a hypoxia process when the photosynthesis stops at night. Dissolved oxygen is used as indicator to evaluate the health on aquatic system, because the hypoxia or anoxia has a significant effect (Breitburg, 2002).

\subsection{Nitrogen}

Predominant species in the inorganic compounds of the nitrogen cycle was the nitrate contained average of $4.24 \pm 5.55 \mu \mathrm{mol} / \mathrm{L}$ ranged between 0.19 and $22.85 \mu \mathrm{mol} / \mathrm{L}$ (Table 1 ). The highest concentrations of this variable was observed on February cruise (Figure 6a).

The concentrations variability suggests periods of a high consumption by the primary producers that alternate with nitrification and un-nitrification processes. The ammonia values variability was from 0.60 to $7.65 \mu \mathrm{mol} / \mathrm{L}$ (Table 1 ), although the concentrations were very heterogeneous predominating values above of $0.05 \mathrm{mg} / \mathrm{L}$ (average of $2.77 \mu \mathrm{mol} / \mathrm{L}$ ). It is important to highlight that $0.05 \mu \mathrm{mol} / \mathrm{L}$ is the highest limit value established by NC-25 (Cuba, 1999 b) to consider marine water with bad quality for fishing use.

In agreement with the ammonia concentrations was the nitrate behavior on the estuary. This could be considered as an oligotrophy tendency, because of the reduction of the phytoplankton consumption rate (De la Lanza and Rodríguez, 1992). The organic and total nitrogen had a great variability with average values of $43.84 \pm 36.09 \mu \mathrm{mol} / \mathrm{L}$ and 
$51.58 \pm 38.77 \mu \mathrm{mol} / \mathrm{L}$ respectively. The highest total nitrogen contents was measure in May 2007 (Figure 4b), in the sampling points E-1 and E-2, taking into account Rabalais et al.(1996) this amount are typical of eutrophicated marine water (Table 1).

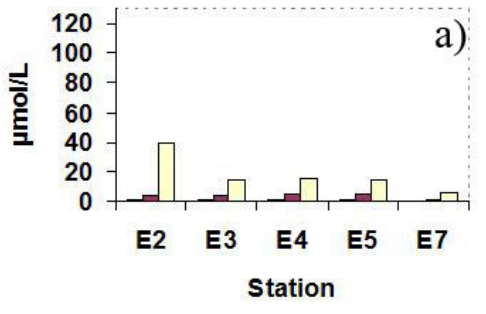

$\square \mathrm{NH} 4 \square \mathrm{NO} 2+\mathrm{NO} 3 \square \mathrm{TN}$

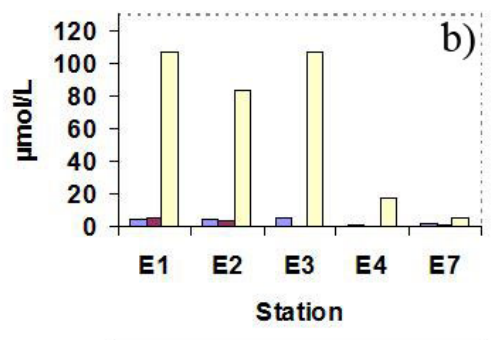

$\square \mathrm{NH} 4 \square \mathrm{NO} 2+\mathrm{NO} 3 \square \mathrm{TN}$

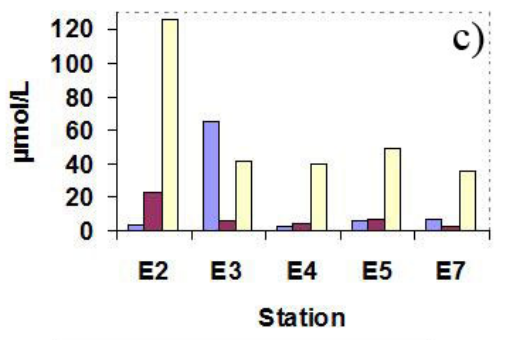

$\square \mathrm{NH} 4 \square \mathrm{NO} 2+\mathrm{NO} 3 \square \mathrm{TN}$

Figure 6. Distribution of the $\mathrm{NH} 4(\mu \mathrm{mol} / \mathrm{L}), \mathrm{NO} 3+\mathrm{NO} 2(\mu \mathrm{mol} / \mathrm{L})$ and $\mathrm{NT}(\mu \mathrm{mol} / \mathrm{L})$ on $(a)$ February 2006, (b) May 2007 and (c) October 2007.

\subsection{Phosphorus}

The inorganic phosphorus $\left(\mathrm{PO}_{4}\right)$ represents $35 \%$ of total phosphorus (TP) the first one concentration was near the limit of the method detection in the sampling points E-3 and E-7 on May 2007. In this measurement campaign was observed the absolute maximum of phosphate in E-4, influenced by the contributions of the lagoon (Figure 7b, Table 1).
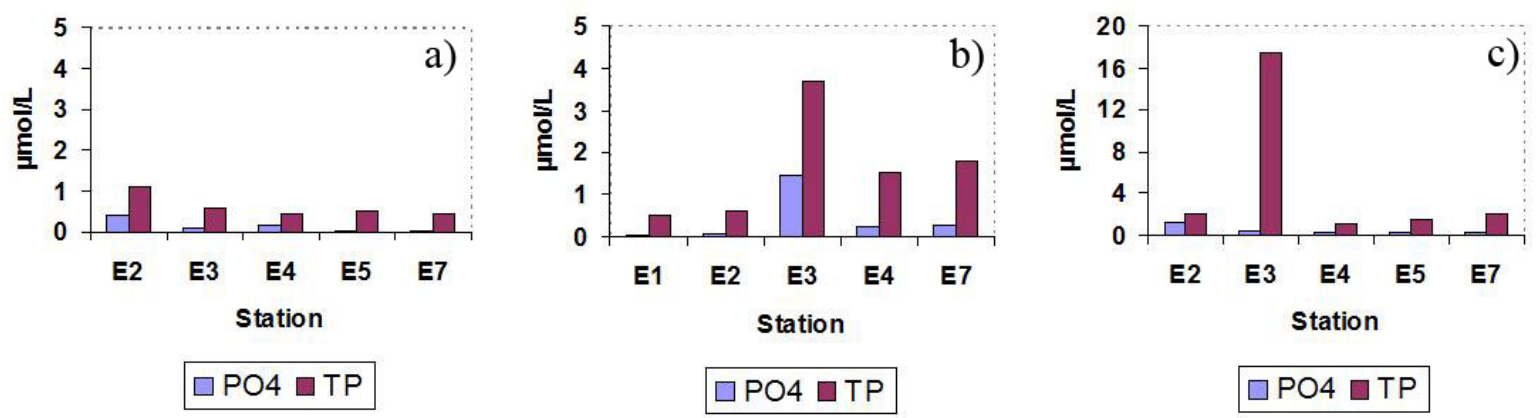

Figure 7. Distribution of the PO4 $(\mu \mathrm{mol} / \mathrm{L})$ and Total Phosphorus (TP) $(\mu \mathrm{mol} / \mathrm{L})$ on (a) Febrary 2006, (b) May 2007 and (c) October 2007.

The total phosphorus content were not homogenous, the absolute maximum was moderate for the bottom level in E-3 with $3.85 \mu \mathrm{mol} / \mathrm{L}$ on October 2007; also in this sampling the point E-7 had an appreciable phosphorus content (Figure 7c). The quantities of phosphorus found in this estuary are typical of a rich phosphorus system, because it interacts with domestic residual forming a very contaminated water body (De la Lanza and Cáceres, 1994).

\subsection{Sanitary state}

During the samplings were obtained, in all the cases, values of thermotolerant coliforms above $200 \mathrm{NMP} / 100 \mathrm{~mL}$, this is the maximum permissible value established by the Cuban norm (Cuba, 1999a). The worse conditions was observed on October 2007 $(900 \mathrm{NMP} / 100 \mathrm{~mL})$, which put in evidence the bad quality of these waters for the sea bath. The concentrations of total coliforms as well as the faecal streptococci were over the water quality norm, locally in the centre point (E-4) and in E-5 near the river mouth (Table 3). Mainly around the communicate point with "El Doctor" lagoon the microbiological indicators showed high levels of faecal contamination.

In general was observed a moderate faecal contamination in the Baracoa River, that became critical in October due to the samples were taken under a strong and constant rainfall. The precipitations cause an increase of the groundwater discharge and therefore an increase of the coliforms group levels (Figueras et al., 2000). 
In the Baracoa River the polluting load is represented by organic matter and faecal bacteria (Table 3). These matters are well-known, as causes of diseases of hydrological origin, such as gastrointestinal diseases, respiratory infections and nasal cavity, eyes and skin infections. The percentage of those morbi-mortality and diseases generate annoyances in population (FAO/OMS, 2004).

Table 3. Concentrations of total coliforms, thermotolerant coliforms and faecal streptococci on the estuary, the marked ones (*) indicate that they are out of the established quality norms (Cuba, 1999a) for the sanitary indicators of hygienic quality.

\begin{tabular}{|c|c|c|c|}
\hline Station & $\begin{array}{c}\text { Total Coliforms } \\
\text { (NMP/100mL) }\end{array}$ & $\begin{array}{c}\text { Thermotolerant } \\
\text { Coliforms (NMP/100mL) } \\
\end{array}$ & $\begin{array}{c}\text { Faecal streptococci } \\
\text { (NMP/100mL) }\end{array}$ \\
\hline \multicolumn{4}{|c|}{$\begin{array}{l}\text { Cruise of February. } \\
2006\end{array}$} \\
\hline 4 & $1100 *$ & $460 *$ & 23 \\
\hline 5 & 240 & $240 *$ & $240 *$ \\
\hline 7 & $1100 *$ & $460 *$ & 15 \\
\hline \multicolumn{4}{|l|}{$\begin{array}{l}\text { Cruise of May. } \\
2007\end{array}$} \\
\hline 4 & $1100 *$ & $460 *$ & 23 \\
\hline 5 & 240 & $240 *$ & $240 *$ \\
\hline 7 & $1100 *$ & $460 *$ & 15 \\
\hline \multicolumn{4}{|c|}{$\begin{array}{l}\text { Cruise of October. } \\
2007\end{array}$} \\
\hline 4 & $1100 *$ & $1100 *$ & $240 *$ \\
\hline 5 & $1100 *$ & $900 *$ & $240 *$ \\
\hline 6 & 900 & $900 *$ & $160 *$ \\
\hline 7 & 900 & $900 *$ & 140 \\
\hline
\end{tabular}

\section{CONCLUSIONS}

Although it is believed that estuaries receive their primary freshwater input from fluvial discharge, there is good evidence that direct groundwater discharge may be responsible for up to $10 \%$ of the total freshwater input to estuaries and also to the ocean. The space distribution of the measure physical and chemical parameters suggests that the estuary is dominated by the marine conditions. The analysis of salinity and temperature, as well as the non conservative behavior of the nutrients show that in general the characteristics of the estuary could be influenced by the contribution of the river basin draining through rainfall.

In general, concentrations of the parameters measured on the Baracoa River estuary, strongly suggest that its area is hitting by the human activities on the river basin, due to the low levels of oxygen dissolved and an oxygen average deficit of $-1.6 \mathrm{mg} / \mathrm{L}$.

Anthropogenic actions in this estuary are mainly related to the emission of domestic and farming remainders without the suitable treatment. This is visibly associated to the observed values of the total coliforms concentrations as well as the concentration of faecal streptococci, that were surpassed reference values from the Cuban norm for water quality, characterizing itself like bad or doubtful quality pointing out negative measurements made next to the communication channel between the estuary and the El Doctor lagoon.

Concentrations of some nutrients measured on the first and second stations were typical of scenes described as eutrophicated aquatic atmospheres characteristic. It is possible to stand out that the present study results are referred to a few amount of sampling, due to this reason it will be necessary new campaigns of systematic samplings to characterize the Baracoa River estuary climatologically. 


\section{REFERENCES}

AMERICAN PUBLIC HEALT ASSOCIATION; AMERICAN WATER WORKS ASSOCIATION; WATER ENVIRONMENTAL FEDERATION. Standard methods for the examination of water and wastewaters. 15. ed. Washington, D.C.: APHA, AWWA, WEF, 1992. 856 p.

BAISRE, J. A. Chronicle of cuban marine fisheries (1935 - 1995). Trend analysis and fisheries potential. FAO Fisheries Technical Paper, n. 394, p. 1-26, 2000.

BAISRE, J. A. La pesca marítima en Cuba. Editorial cientifico - técnica. La Habana: Instituto del libro, 2004. 372 p.

BENDIS, B. Water quality trends in Tampa Bay, Florida. 1999. M. S. Thesis - University of South Florida, Tampa, 1999.

BREITBURG, D. Effects of hypoxia and the balance between hypoxia and enrichment on coastal fishers and fisheries. Estuaries, n. 25, p. 767-781, 2002. http://dx.doi.org/10.1007/BF02804904.

CLOERN, J. E. Our evolving conceptual model of the coastal eutrophication problem. Mar. Ecol. Prog. Ser., v.. 210, p. 223-253, 2001.

http://dx.doi.org/10.3354/meps210223.

COMISIÓN NACIONAL DE NOMBRES GEOGRÁFICOS - CNNG. Diccionario geográfico de Cuba. La Habana: CNNG, 2000. 386 p. ISBN: 959-7049-08-2.

CONTRERAS, F. Ecosistemas costeros mexicanos. Izla-palala: Universidad Autónoma Metropolitana; Comisión Nac. para el conocimiento y uso de la biodiversidad, 1993. 415 p.

DE LA LANZA, G.; RODRÍGUEZ, A. Nutrient exchange between subtropical lagoons and the marine environment. Estuaries, v. 16, n. 2, p. 273-279, 1992.

DE LA LANZA, G.; CÁCERES, C. Lagunas costeras del litoral mexicano. U. A. de Baja California Sur, 1994. 525 p.

FOOD AND AGRICULTURE ORGANIZATION - FAO. Manual of methods in aquatic enviroment research. Part 1. Methods for detection. measurement and monitoring of water pollution. FAO Fish. Tech. Pap. 1975. 237p.

FOOD AND AGRICULTURE ORGANIZATION - FAO/OMS. Caracterización de peligros de patógenos en alimentos y en agua. Serie de evaluación de riesgos microbiológicos. FAO, 2004. 59 p.

FIGUERAS, M. J.; BORREGO, J. J.; PIKE, E. B.; ROBERTSON, W.; ASHBOLT, Y. N. Sanitary inspection and microbiological water quality. In: WORL HEALTH ORGANIZATION. Monitoring bathing waters: a practical guide to the design and implementation of assessments and monitoring programmes. WHO, 2000. p 114-167.

GONZÁLEZ SANSÓN, G. Biodiversidad marina y desarrollo: conflictos y soluciones en el Caribe. Cádiz: Universidad, Servicio de Publicaciones, 2002. 150 p. INTERGOVERNMENTAL OCEANOGRAPHIC COMMISSION - IOC-UNESCO. Nutrient analysis in tropical marine waters. IOC, 1993. (Manual and guides, n. 33).

JAPAN. Environmental quality standard for water pollution (EQS). 2002. Available in: $<$ http://www.env.go.jp/en/water/wq/wp.pdf >. Access in: 20 Apr. 2010. 
KJERFVE, B. Estuarine geomorphology and physical oceanography. In: DAY Jr., J. W.; HALL, C. A. S.; KEMP, W. M.; YÁNEZ-ARANCIBIA, A. (eds.). Estuarine ecology. New York: Wiley, 1987. p. 47-48.

LAUFF. G.T. Estuaries. In: AMERICAN ASSOCIATION FOR THE ADVANCEMENT OF SCIENCE. Washington: AAAS, 1962. 757p. Publ. 83.

MARINS, R. V.; LACERDA, L. D.; ABREU, I. M.; DÍAS, F. J. S. Efeitos da açudagem no rio Jaguaribe. Ciência Hoje, v. 33, n. 197, p. 66-70, 2003.

MONTALVO, J. F.; PERIGÓ, E. Niveles de oxígeno disuelto y materia orgánica en lagunas costeras de las regiones central y oriental de Cuba. Contribución a la Educación y la Protección Ambiental, v. p. 126-129, 1999.

CUBA. Lugares de baños en costas y en masas de aguas interiores. Norma Cubana n. 22. Requisitos higiénicos sanitarios. La Habana: , 1999a.

CUBA. Sistema de normas para la protección del medio ambiente. Norma Cubana n. 25. Hidrosfera. Especificaciones y procedimientos para la evaluación de los objetos hídricos de uso pesquero. La Habana, 1999b.

PERIGÓ, A. E.; PERIGÓ, J. F.; MONTALVO, E.; CHANG, M. E.; CESAR, R.; GARCÍA, I. A. Evaluación de factores hidroquímicos indicadores de contaminación orgánica en la laguna costera El Doctor, Playa Baracoa, Cuba. Rev. Cub. Invest. Pesq., v. 36, p. 12-16, 2006.

PERIGÓ, E.; RAMÍREZ, O.; MONTALVO, J. et al. Diagnóstico ambiental de la laguna costera el doctor, playa de Baracoa, Bauta: impactos y respuestas. Contribución a la Educación y la Protección Ambiental, v. 8, p. 162-172, 2008.

PERIGÓ. E.; ÁlVAREZ, A.; MONTALVO, J. F.; RODAS, L.; MARTELL, R.; NIÉVARES, A.; PEÓN, C.; ESPONDA, S. Aplicación de los modelos de simulación hidronuméricos en el estudio de la contaminación del río Las Casas. Contribución a la Educación y la Protección Ambiental, v. 3, 2002.

PERIGÓ, E.; MONTALVO, J. F.;GARCÍA, I. A. Impacto ambiental en ecosistemas litorales del sur de la provincia de Sancti Spiritus (Cuba). Contribución a la Educación y la Protección Ambiental, p. 220-224, 1999.

PIERRE CARMOUZE. J. O metabolismo do ecosistemas acuáticos. Fundamentos teóricos. In:

Métodos de estudios de análisis químicos. [S.1.]: FAPEST, 1994. 251 p.

RABALAIS, N. N.;TURNER, R. E.; JUSTIC, D.; DORTCH, Q.; WISEMAN JR., W. J.; SEN GUPTA, B. K. Nutrient changes in the Mississippi River and system responses on the adjacent continental shelf. Estuaries, v. 19, n. 2B, p. 386-407, 1996. http://dx.doi.org/10.2307/1352458. 